\title{
Effect of Extended Transit and Temperature Variations on EID50 Values of Thermostable NDVI-2 Vaccines
}

\author{
A. N. Egbuji, A. A. Chukwuedo, L. N. Shedua, J. K. Gyallak, L. N. Swomen, M. Muhammad, \\ C. I. Nwosuh, L. U. Enurah
}

\section{ABSTRACT}

\begin{abstract}
Temperature alterations due to poor cold keeping condition have consistently posed a challenge to vaccines dose EID50 titre value. The sensitivity of Newcastle disease vaccine to temperature variations due to poor cold storage condition in rural settings, led to the development of the NDVI-2 thermostable vaccine, which is known to exhibit a thermostability of 3 hours at $56^{\circ} \mathrm{C}$. In this study, three Newcastle disease vaccines (NDVI-2) with EID50 titre per dose values of $\log _{10} E I D 507.7,7.6$ and 6.75 respectively from vaccine production facility at the National Veterinary Research Institute (NVRI), Vom Nigeria, were sent for certification at African Union laboratory at Debre Zeit, Ethiopia under cold condition; using ice packs for cold chain maintenance. Tracking of the vaccine in the course of freight to the certifying laboratory revealed changes in the original transit route by the airline and delay by custom at the receiving country port. Thus, a 12 hours transit freight was delayed for over 7 days before arrival at the certifying laboratory. Though, the EID50 titre per dose values of these vaccines were originally well above recommended EID50 5.5 per dose value by $\log 2.2, \log$ 2.1 and $\log 1.25$ for NDVI-2 respectively. Comparing these vaccines EID50 values obtained from the certifying laboratory in relation to values initially obtained by the Quality Control Division of the producing Institute (NVRI), revealed loss of EID50 titre per dose value by $\log _{101.2}$, and $\log _{10} 0.8$ among two of the certified vaccine batches; with one of the certified vaccines retaining its original EID50 titre per dose value. This result attest that NDVI2 thermostable vaccine produced at NVRI, Vom Nigeria are robust and of high quality. Thus, the findings of this study have further demonstrated that temperature variations, prolonged vaccine transportation under poor cold chain can affect the EID50 per dose value of a wholesome, field fit vaccine irrespective of the vaccine thermostability.
\end{abstract}

Keywords: Transit Cold Condition Alterations, EID50 per Dose Values, Thermostable Newcastle Disease Vaccine.
Published Online: September 19, 2020

ISSN: 2684-5199

DOI : 10.24018/ejbio.2020.1.5.76

\section{A. N. Egbuji*}

National Veterinary Research Institute, Vom, Plateau State, Nigeria.

(e-mail: wisemenvet@yahoo.com)

A. A. Chukwuedo

National Veterinary Research Institute, Vom, Plateau State, Nigeria.

L. N. Shedua

National Veterinary Research Institute, Vom, Plateau State, Nigeria.

J. K. Gyallak

National Veterinary Research Institute, Vom, Plateau State, Nigeria.

L. N. Swomen

National Veterinary Research Institute, Vom, Plateau State, Nigeria.

M. Muhammad

National Veterinary Research Institute,

Vom, Plateau State, Nigeria.

C. I. Nwosuh

National Veterinary Research Institute,

Vom, Plateau State, Nigeria.

L. U. Enurah

National Veterinary Research Institute, Vom, Plateau State, Nigeria.

*Corresponding Author

\section{INTRODUCTION}

Newcastle disease (ND) is caused by virulent strains of avian paramyxovirus type 1 (APMV-1) an envelope, single stranded RNA virus [1]. The disease is a highly contagious, rapidly spreading viral disease of domestic poultry of all ages and other wild avian species and the disease consequences is devastating in susceptible poultry flock [2]-[6]. Newcastle disease is endemic in Nigeria [7] and it is generally wellrecognized by farmers in both local and exotic breed of birds [8]. Outbreak is reportable to World Organization of Animal Health [1]. The most cost-effective control strategy for Newcastle disease outbreak is by vaccination [9]. The first successful control measure against Newcastle disease in Nigeria was through the production of Newcastle disease intra ocular (NDV-i/o) and Newcastle disease Komarov $(\mathrm{NDV}-\mathrm{K})$ by the then Federal Veterinary Research Laboratory, Vom [10]; presently known as the National Veterinary Research Institute (NVRI). Biosecurity measures are possible control alternative for $\mathrm{ND}$, however, its application has remains difficult or impossible to implement in rural setting due to the nomadic and free-range rearing of village poultry in Nigeria [11]. In commercial poultry production in Nigeria a regimented Newcastle disease vaccination program is widely applied for the protection of commercial poultry flocks against Newcastle disease outbreaks.

Conventional vaccination programs for Newcastle disease control in endemic regions include the use of either lowvirulent live-virus vaccines or inactivated vaccines to induce protective immunity while producing minimal adverse reaction in birds [12]. Inactivated oil-emulsion vaccines are manufactured for use by individual bird injection. On the other hand, low-virulent infectious virus may be ingested or inhaled, and this is the basis for mass application of live-virus vaccines in drinking water or by large aerosol droplet [12]. Birds may also be inoculated with eye drops containing vaccines based on attenuated viruses. Vaccination using non virulent ND virus strains to protect susceptible birds against 
ND disease outbreak by eliciting the production of specific antibody response either locally, systemically or both [12].

This study was carried out to compare EID50 per dose titre values of three thermostable vaccines after production inrelation to values obtained after certification; and an unnecessarily prolonged transit. The study revealed that temperature alterations, prolonged extended transit can affect a naturally thermostable vaccine EID50 per dose titre value. Thus, irrespective of a vaccine thermostability nature and its EID50 after production, temperature variations, poor cold keeping condition, can affect its EID50 per dose value.

\section{MAterials AND METHOD}

\section{A. EID50 Values Determination}

The EID50 values of a batch of ND (NDVI-2) of 50 dose and two batches of (NDVI-2) of 200 doses respectively produced by the National Veterinary Research Institute (NVRI), Vom were determined after inoculation in 10-day old embryonated chicken eggs following OIE, [13] standard protocol. The vaccine virus titres (concentration per dose) were calculated and determined according to Karber method [14].

\section{B. Vaccine shipment tracking history}

The vaccine original shipments envisaged route:

Vom to Abuja airport - 4 hours; Abuja to Adis-ababa - 6 hours; Adis-ababa airport to Debre Zeit -2 hours

The vaccine actual shipments route:

Vom to Abuja airport 4 hour; Abuja airport to Adis-ababa airport - 6 hours; Adis-ababa airport to Nairobi airport -2 days; Nairobi airport to Adis-ababa airport - 3 days; Adisababa airport to Debre Zeit - 2 days.

\section{RESULT}

Application of the Karber method for vaccine dose assay using karber method [14] revealed EID50 titre values of $\log 10$ EID50 7.7, 7.6 and 6.75 per dose respectively for the titrated vaccines prior to shipment. This is $\log 102.2, \log 10$ 2.1 and $\log 101.25$ above the recommended reference EID50 values of $\log 105.5$ per dose for NDVI-2 (Table 1).

TABLE 1: INITIAL EID50 VALUES AFTER PRODUCTION IN COMPARISON TO REFERENCE EID50 VALUES FOR NDVI-2 VACCINE

\begin{tabular}{cccc}
\hline $\begin{array}{c}\text { Vaccine type } \\
\text { and dose } \\
\text { (NDVI-2) }\end{array}$ & $\begin{array}{c}\text { EID50 per dose } \\
\text { value after } \\
\text { production }\end{array}$ & $\begin{array}{c}\text { Reference } \\
\text { EID50 per } \\
\text { dose Value }\end{array}$ & $\begin{array}{c}\text { Titre per dose } \\
\text { value above } \\
\text { reference } \\
\text { EID50 }\end{array}$ \\
\hline 50 & $\begin{array}{c}\log 107.7 \text { per } \\
\text { dose }\end{array}$ & $\begin{array}{c}\log 105.5 \text { per } \\
\text { dose }\end{array}$ & $\log 102.2$, \\
200 & $\begin{array}{c}\log 107.6 \text { per } \\
\text { dose }\end{array}$ & $\begin{array}{c}\log 105.5 \text { per } \\
\text { dose }\end{array}$ & $\log 102.1$ \\
200 & $\begin{array}{c}\log 6.75 \text { per } \\
\text { dose }\end{array}$ & $\begin{array}{c}\log 105.5 \text { per } \\
\text { dose }\end{array}$ & $\log 101.25$ \\
\hline
\end{tabular}

However, loss of EID50 titre values in two out of the three vaccines that were sent for certification was observed. Two out of the three vaccine samples (batches) certified showed EID50 titre per dose value $\operatorname{loss}$ of $\log 1.2$ and $\log 0.8$ when the results of certifying laboratory were compared with values originally obtained by the Quality Control laboratory of the vaccine production Institute (Table II). Therefore, due to extra $\log 10$ EID50 values per dose in- cooperated in each of these vaccine batches originally by the producers, the vaccine dose value was still within acceptable dose per range for NDVI-2 despite the obvious titre loss or drop after certification.

TABLE II: COMPARISON OF EID50 VALUES AND LOG10 DIFFERENCE VALUES FOR NDVI-2 VACCINE AFTER EXTENDED TRANSIT

\begin{tabular}{cccc}
\hline $\begin{array}{c}\text { Vaccine } \\
\text { type } \\
\text { and dose }\end{array}$ & $\begin{array}{c}\text { Certifying } \\
\text { Laboratory EID50 } \\
\text { Values }\end{array}$ & $\begin{array}{c}\text { Reference } \\
\text { EID50 Values }\end{array}$ & $\begin{array}{c}\text { EID50 value } \\
\text { Loss after } \\
\text { transportation }\end{array}$ \\
\hline 50 & $\begin{array}{c}\log 106.5 \text { per } \\
\text { dose }\end{array}$ & $\begin{array}{c}\log 105.5 \text { per } \\
\text { dose }\end{array}$ & $\log 101.2$ \\
200 & $\begin{array}{c}\log 106.8 \text { per } \\
\text { dose }\end{array}$ & $\begin{array}{c}\log 105.5 \text { per } \\
\text { dose }\end{array}$ & $\log 100.8$ \\
200 & $\begin{array}{c}\log 106.75 \text { per } \\
\text { dose }\end{array}$ & $\begin{array}{c}\log 105.5 \text { per } \\
\text { dose }\end{array}$ & nil \\
\hline
\end{tabular}

\section{DISCUSSION}

Field vaccination control strategy for Newcastle disease outbreak in susceptible poultry flock is only achievable by the use of field fit, safe, efficacious and wholesome Newcastle disease vaccines [15], especially in endemic region. The findings of our study demonstrated that prolonged extended transportation of a naturally thermostable vaccine with poor cold condition maintianance can result in loss of EID50 titre per dose value. The three vaccines originally showed EID50 titre values of $\log 107.7,7.6$ and 6.75 per dose, to a recommended reference EID50 titre value of $\log 105.5$ per dose. This is $\log 2.2,2.1$ and 1.25 above the required or recommended EID50 titre per dose for field application of NDVI-2. The prolonged freight; change of freight destination and clearance delay at the point of entry were attributable factors responsible for the observed EID50 titre value loss of $\log 1.2$, and 0.8 by two of three vaccine batches while one out of the three vaccines retained its original EID50 titre value. The NDVI-2 vaccine is thermostable by nature and can withstand weak cold conditions; the finding of this study has demonstrated NDVI-2 vaccine thermostable ability. However, this ability to withstand poor cold storage condition does not exempt a naturally thermostable NDVI-2 vaccine from EID50 titre per dose loss or drop. Therefore, a thermostable vaccine should equally be handled with utmost caution and under good cold keeping conditions, bearing in mind that titre drop, or loss is absolutely very possible if the vaccine cold keeping condition is compromised.

The finding of [16] and [17] suggested that in situations where the cold chain maintenance is difficult, the only reliable alternative may be the use of thermostable ND vaccines; such as the NDVI-2, NDV4-HR and or inactivated vaccines. The findings of our study support the claims of [16], [17]; this is attributable to the robustness of NDVI-2 vaccine virus to remain viable even with limited cold storage or keeping condition and extended prolonged transit, as demonstrated.

The unpredictable vaccine transit routes, temperature variations and handling in the field setting before getting to the end users are factors Newcastle disease vaccine producers should be conscious of when compounding thermostable and thermolabile Newcastle disease vaccines. The producers should as much as possible ensure that qualitative vaccine with EID50 titre value of at least $\log 2$ or $\log 3$ above 
recommended standard EID50 value be in-cooperated in their vaccines when compounding; to carter for possible loss of EID50 titre values, which might be the consequent impact of poor handling, temperature variations and possibly extended transportation duration with poor cold keeping condition.

Thus, in countries where ND is endemic, the use of certified, wholesome, highly efficacious, safe and field fit ND vaccine is of optimal priority to both the vaccine producers and the poultry farmers. Furthermore, Veterinary Authorities in Africa should ensure that the ND vaccines produced and used in various counties in the continent met the required safety and quality standard to ensure protection of poultry flock against the destructive and enormous economic consequences of ND disease outbreaks; since it has been established that vaccination against ND remains the major control strategy against this poultry disease [18], [19], [20] and [21]. Therefore, whether a vaccine is produced locally or imported, each batch should be tested by African Union certifying laboratory to ensure conformity of the vaccine or vaccines to required, expected and acceptable standard, prior to field application or use.

It is imperative therefore, that vaccine end users understand that a thermostable vaccine must be handled with optimal precaution accorded other vaccines or biologicals since these vaccines are equally liable and susceptible to titre loss due to poor cold keeping condition. Furthermore, vaccine cannot be exposed to sunlight or frequent changes or variations in temperature and still be expected to remain viable [22]. Therefore, the use of safe, efficacious, highly potent and wholesome vaccine for the strategic control of Newcastle disease in endemic region should be of utmost priority to regional governments and Veterinary authorities across the continent.

A thermostable vaccine reduces the challenges encountered by distributors and vaccine end users especially as it relates to poor cold chains maintenance under field situations; as it is usually encountered in developing countries, where electricity supply is inadequate. This study has shown that avoidable cold condition alterations, variations and unnecessarily prolong transport situation can alter vaccine EID50 titre value of a naturally thermostable vaccine. The extra EID50 values of 2.2, 2.1 and 1.25 above the recommended EID50 value ensured that despite the observable titre loss, these vaccines were well within expected and acceptable recommended EID50 value range for NDVI-2 intended for field use. Thus, vaccine producers should always make provision for additional EID50 value when compounding their vaccine to compensate for possible EID50 value loss these vaccines might encounter once it is beyond their care and control.

\section{ACKNOWLEDGEMENT}

We are grateful to Mrs. Fatima B. Mukaila, Mr. Sati Lokason, Mr. Oga Onojah of the Quality Control Division, National Veterinary Research Institute, Vom Nigeria for their technical assistance and role in vaccine sterility, safety assay.

\section{REFERENCES}

[1] OIE, (2013). Office of International Epizootics - Terrestrial Manual of Standards.

[2] B.S. Seal, D.J. King, H.S. Seller. "The avian response to Newcastle disease virus", Dev. Comparative Immunology. Vol. 24, pp. 257-268, 2000 .

[3] E.W. Aldous, J.K. Mynn, D.J. Alexander. "A molecular epidemiology study of avian paramyxovirus type 1 (Newcastle disease) isolate by phylogenetic analysis of a partial nucleotide sequence of the fusion protein gene", Avian Pathology, Vol. 32, pp. 239-256, 2003.

[4] D. J. Alexander, and R. F. Jones. "Newcastle disease, other paramyxovirus and pneumovirus infections". In: Y.M. Saif (Ed) Diseases of poultry, Iowa State Press, pp. 63-92. 2003.

[5] M.H. Haque, M.T. Hossain, M. T. Islam, M.A. Zinnah, M.S.R. Khan, M.A. Islam." Isolation and Detection of Newcastle disease virus from field outbreaks in Broiler and Layer chickens by Reverse Transcription-Polymerase chain reaction". Journal. Veterinary Medicine. Vol. 8, pp. 87-92, 2010.

[6] N. Iran, M.S. Shah, F. Ismat, M. Habib, M. Iqbal, S.S. Hasnain, M. Rahman." Heterologous expression, characterization and evaluation of the matrix protein from Newcastle disease virus as a target for antiviral therapies". Applied. Microbiology and Biotechnology. Vol. 9, pp. 1691701, 2013.

[7] L. Sa'idu, P.A., Abdu and E.L. Markus: "Retrospective studies on Newcastle disease in vaccinated flocks in Zaria, Nigeria". Student Veterinarian, Vol. 17, pp. 27-31, 1998.

[8] J.R .Lawal, S.M. Jajere, M. Mustapha, A.M. Bello, Y. Wakil, Y.A. Geidam, U.I .Ibrahim, I.A Gulani. "Prevalence of Newcastle Disease in Gombe, North-eastern Nigeria: A Ten-Year Retrospective Study (2004 -2013)", British. Microbiology. Research. Journal, Vol. 6, pp. 367-375, 2015.

[9] T. Lurthu, Reetha, Johnson, J. Rajeswar. T. J. HariKrishnan, K. Sukumar, P. Srinivasan, J. John Kirubakaran" Studies on the effectiveness of oral pellet vaccine in improving egg production and egg quality in desk chicken". Veterinary World, Vol. 9, pp. 900-903, 2016.

[10] R.P. Hanson (1972)." Newcastle disease. In: Diseases of Poultry 6th Ed. Edited by M.S. Hofstad Iowa State University Press.

[11] Anthony N. Egbuji, John O. Ibu, Ismaila A. Shittu, Dauda G. Bwala, Anne. S. Lohlum, Josephine Kiagama, Evelyn D. Dung, Uwanibe L.Enurah, Fatima B Mukaila, Dung S Lokason, Chinemerem. R Obene, Choji A Kwanga, Nicodemus M. Useh, Paul A Abdul, Usman Musa, John A. Okoye, Jude S. Rabo "Immune Profiling of Grain Adapted I2 (GAI-2) Pelleted Feed Vaccine in 6 Weeks Old Cockerels in Vom Nigeria”, Journal of Experimental Biology and Agricultural Sciences, Vol. 5, pp. 599-605, 2017.

[12] Zoth, S. Chimeno, E.Gómez, E. Carrillo, and A. Berinstein.” Locally produced mucosal IgG in chickens immunized with conventional vaccines for Newcastle disease virus", Brazilian Journal of Medical and Biological Research, Vol. 41, pp. 318-323.2008 ISSN 0100-879X.

[13] OIE." Office of International Epizootics - Terrestrial Manual of Standards". 2010 .

[14] G. Karber. "50\% end point calculation." Archive für Experimentelle Pathologie Pharmakologie, Vol. 162: pp 480-483. 1931.

[15] A.N. Egbuji, A. Chukwuedo, L.N. Shedua, J.K. Gyallak, L.N. Swomen, N.C. Obene, U.K. Akachi, H.N. Chijioke, K.O. Idahor, Muhammad, M. and Enurah, L. U. "Overdose Administration of Thermostable Newcastle Disease Vaccines to Naïve Unvaccinated 6 Weeks Old Cockerels at NVRI, Vom Plateau state, Nigeria". Journal of Advances in Microbiology, Vol. 20, pp. 29-34, 2020.

[16] Ideris, A.L. Ibrahim, P.E. Spradbrow, and C. Hung Seng” Development of Food Pellet Newcastle Disease Vaccine". In: Copland, J.W., ed. Newcastle Disease in Poultry: A New Food Pellet Vaccine. Canberra, ACIAR, 20-23. Implication for diagnosis and control. Book of proceedings 29 $9^{\text {th }}$ November-1st December 1987.

[17] Z. Bensink and P.Spradbrow. "Newcastle disease virus strain I-2- a prospective thermostable vaccine for use in developing countries". Veterinary Microbiology, Vol. 68, pp. 131-139, 1999.

[18] W.H. Allan, J.E. Lancaster. and B. Toth. "Newcastle disease vaccinestheir production and use", FAO Animal Production Series No. 10. FAO, Rome. 1978

[19] Aini, A.L. Ibrahim and P.B. Spradbrow. "Field trials of a food-based vaccine to protect village chickens against Newcastle disease". Research in Veterinary Science, Vol. 49, pp. 216 - 219, 1990

[20] L.J.E. Orajaka, D.F. Adene, B.M. Anene, and E.A.Onuoha. "Seroprevalence of Newcastle disease in local chickens from Southeast derived savannah zone of Nigeria", Revue Elev. Med. Vet. Pays. Trop; No 52, Vol. 3-4, pp. 185-188,1999. 
[21] M. Usman. "Effects of vaccination of chickens against Newcastle diseases with thermostable V4 and La Sota vaccines“, MSc Thesis. Department of Veterinary Surgery and Medicine, Ahmadu Bello University, Zaria, Nigeria, 2002.

[22] R.G. Alders and P.B. Spradbrow. "Controlling Newcastle Disease in Village Chickens": a field manual. Canberra, Australian Centre for International Agricultural Research. Monograph 82. 112pp. 2001a.

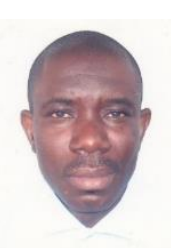

Dr. Anthony N. Egbuji He holds a Doctor Veterinary Medicine (DVM, 1999) degree from University of Nigeria Nsukka, a Master of Science (MSc.) degree in Avian Medicine from the same University, and $\mathrm{PhD}$ degree in Veterinary Microbiology (Virology) from the University of Agriculture Makurdi, Nigeria, where he worked extensively on the development of NDVI-2 vaccine variant known as NDVI-2-6 used for the control of Newcastle disease in rural poultry. The NDVI-2-6 vaccine can be prepared in either lyophzed form for intra-ocular/ intra-nasal inoculation or in pelleted feed form using Digitalia as vaccine virus carrier of the feed vaccine for easy administration in rural poultry.

He has worked for 17 years at the National Veterinary Research Institute (NVRI), Vom, Plateau State, Nigeria as a Veterinary Research Officer. He has also worked as a Veterinary Investigation Officer at NVRI, Out-station Laboratory at Umudike, Abia State (2003-2004). He has participated in the Institute's Newcastle disease and Avian Influenza Research Programmes from 2005-2010. Currently, from 2010 to date, he works in Quality Control Division of the Institute.

He contributed a chapter in the book; Vaccines in Developing countries: Need, Production Capacities and Immunization strategies; (2018) (ed) Mahmoud M Bahgat and Ibe Bartholomew. Allied Publishers Pvt Ltd, pp. 82-89; Field Trial of a Newcastle Disease I-2-6 Grain Adapted Pelleted Feed Vaccine (NDVI-2-6 GAPFV) in five selected rural communities in Nigeria. He has over 17 Scientific Publications.

Positions held: He was the Head NVRI, Out-station Laboratory at Umudike, Abia state from 2003-2004, where he worked as the Veterinary Investigation Officer. He was the Principal Investigation Officer for the NDVI-2-6 Pelleted Feed Vaccine Development Research under CARGRS (Competitive Agricultural Research Grant Scheme) from 2013-2017. Presently, he is the Sectional Head of Viral Vaccine Section of Quality Control Division, NVRI, Vom. He is a member of the Institute's Veterinary Research Officer Clinical Conference Presentation and a member of the Nigerian Veterinary Medical Association.

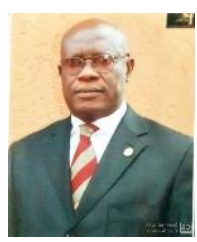

Dr A. A. Chukwuedo Hails from Asaba in Delta state of Nigeria. He works as a Research staff of National Veterinary Research Institute, Vom, Plateau state, Nigeria. $\mathrm{He}$ is currently the Director of Quality Assurance.

He holds a Bachelor of Science (B.Sc., 1984) degree in Microbiology from the University of Ife (now OAU) Osun state, Master of Science (M.Sc., 1990) in virology from University of Ibadan, Ibadan, Oyo state and a PhD (2014) in Medical Microbiology(virology) from the University of Jos, Plateau state, all in Nigeria.

He has over 35 years of working experience as Research Officer in vaccine production (1985 to 2000), teaching, an administrator; Project Leader of Killed adjuvanted cell culture rabies vaccine development(2010 to 2015), Head of Viral Research Division(2014 to 2018); Head, FMD diagnosis and vaccine development laboratory(1996 to 2015); Head, vesicular mucosal disease of large animal section(2014 to 2015) Director, Quality Assurance Department (2019 to date). He has over 60 Scientific Publications.

Positions held in National Scientific Associations and Societies include: National Publicity Secretary, Biotechnology Society of Nigeria (BSN; 1996 to 2000); Secretary general of BSN (2000 to 2003); Editor BSN Newsletters (1996 to 2003); Editorial Board Member BSN Journal (1996 to 2005); Member, Nigerian Society for Microbiology (NSM, 1991 to date), Nigeria Society for Immunology (NSI, 1993 to date), Biotechnology Society of Nigeria (BSN, 1997 to date) and Association of Medical Laboratory Scientist of Nigeria(AMLSN, 2010 to date); Senior Staff Association Service to Humanity Award (1995) and Fellowship Member Award of the Institute of Medical Laboratory Scientists Council of Nigeria (FMLSCN, 2010).

Dr Anthony Chukwuedo is an author and co-author of over 65 Scientific Publications in peer-reviewed journals. He has also attended trainings in Oversea Laboratories; Rabies diagnosis in Onderstepoort Veterinary Institute (OVI) Pretoria South Africa (June,2010 and July 2011), Foot and mouth disease diagnosis in SENSANO (former CODE CERVA) Belgium (Nov. 2017).

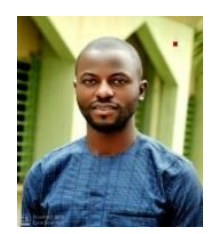

Kingsley Gyallak James Hails from Bokkos LGA of Plateau State Nigeria. A graduate of Bachelor of Science in Microbiology from University of Jos, Plateau state, Nigeria in the year 2015.

Currently he works with the National Veterinary Research Institute, Vom as a Research Officer II.

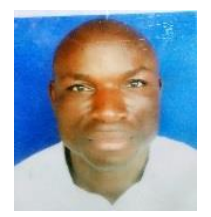

Lawrence Nkwap Swomen Hails from Kwande district, Quaan pan LGA of Plateau State. He went to L.G.E.A Primary School Npap between 1990-1996, attended Government Secondary School Goepa'al-Shendam, Plateau State between 1996-2002 where he obtained National Examinations Council (NECO) certificate, and later sat for WAEC, SSCE in 2016. Attended College of Arts Science and Technology (CAST) Kurgwi, Plateau State between 20042006 where he obtained Interim Joint Matriculation Board Examination (IJMB) Results.

He went to University of Jos Plateau State Nigeria between 2008-2012 where he obtained BSc. Microbiology obtained NYSC certificate of exemption in 2012.He is currently working at National Veterinary Research Institute Vom Plateau State, Nigeria as a Research Officer.

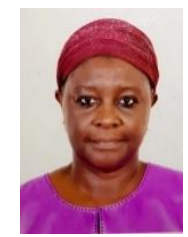

Dr Maryam Muhammad (DVM., ABU Zaria, 1984; MSc., London, 1992; PhD., Unimaid, 2008; FCVSN 2012) was born in Kaduna, Nigeria. She graduated with a DVM degree from Ahmadu Bello University, Zaria, a master's degree in nutrition from the University of London and a PhD in Poultry Medicine from the University of Maiduguri, Nigeria. She has a postgraduate Diploma in Agricultural Education from the Wolverhampton Polytechnic, UK and is a Fellow of the College of Veterinary Surgeons, Nigeria and a Fellow of the Leadership for Environment and Development; a global network of professionals working towards a sustainable environment. Her major field of study is poultry medicine with emphasis in the control of salmonellosis.

She has 35 years of working experience as a Veterinary Research Officer and has held various research and teaching positions at the National Veterinary Research Institute, Vom. She has extensive experience in teaching, research, and administration. She previously served as Chief Veterinary Research Officer conducting research into salmonellosis, campylobacteriosis and listeriosis. She was Principal Investigator on a national research programme for the control of salmonellosis in commercial poultry in Nigeria. She also served as a farm manager supervising farm activities such as poultry production, feed milling and rabbit multiplication programme. Prior to that she was lecturer and course organizer at the Federal College of Animal Health and Production Technology, NVRI Vom and was responsible for course needs, effective delivery of courses and the monitoring of students' progress. She is currently the Director Planning, Information and Documentation with overall responsibility for the activities of the Planning Department including the coordination and formulation of programmes and projects of the Institute, monitoring and evaluation of all planned programmes and projects being implemented by the various departments, participating in policy formulation, annual budgets and manpower development.

Dr Muhammad is a member of the Nigerian Veterinary Medical Association, Biotechnology Society of Nigeria, and the Microbiology Society of Nigeria. Her research interests include the molecular epidemiology of Salmonella in poultry, public health and environment and development. Dr Muhammad has attended trainings and fellowships in diagnostic laboratory management, molecular and serotyping techniques for Salmonella and Campylobacter. She is an award recipient of the British Overseas Development technical trainers award, the Chevening Scholarship award and the Rockefeller Foundation award for Leadership in Environment and Development. Dr Muhammad has forty five published articles, two training manuals and has supervised seventeen ND, HND and PhD student projects. 


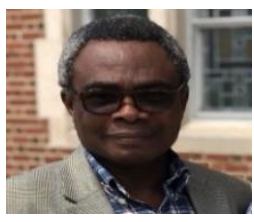

Nwosuh Chika Ignatius Hails from Igboukwu in, Anambra State, Nigeria.

Schools Attended with dates and Qualifications:

Fellow, College of Veterinary Surgeons Nigeria (FCVSN), 2010; Ahmadu Bello University Zaria, Nigeria 2006-2010 PhD; Ahmadu Bello University Zaria, Nigeria 1985-1988 MSc Veterinary Microbiology; University of Ibadan, Ibadan, Nigeria 1973-1979 DVM.

He was head, Viral vaccine production (2002-2012), Coordinator Onderstepoort Veterinary Institute/National Veterinary Research Institute Rabies Twining Project (2010-2016). He is currently Director Research, National Veterinary Research Institute, Vom.

$\mathrm{He}$ has over 50 publications, participated in local and international meetings and conferences.

Dr Nwosuh is a member Nigerian Veterinary medical Association. He has over fifty research publications in international journals and has so many conference papers and workshops to his credit.

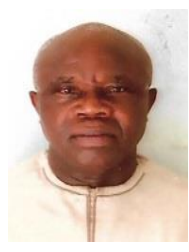

Dr. Leonard Uwanibe Enurah (DVM ,MVSc; Moscow, 1984; MSc, UNIMAID, 2000; PhD. UNILAG, 2011; FCVSN, 2018).

He graduated with Doctor of Veterinary Medicine (DVM) and Master of Veterinary Science (MVSc) degrees from Moscow Veterinary Academy, U.S.S.R. (now Russia) with emphasis in Veterinary Public Health and Preventive Medicine, another Master's Degree in Veterinary Microbiology from the University of Maiduguri and a PhD in Diagnostic Bacteriology from the University of Lagos, he is a Fellow of the College of Veterinary Surgeons, Nigeria (FCVSN). 1984-1985, he worked in Parasitology Division of the Institute. From 1985-1989 he worked in Diagnostic Division of the Institute, From 1989-2002, he was the Veterinary Investigation Officer in charge of Northeast Regional Laboratory in Yola Within this period, he developed and tried successfully on the field a drug known as Lamstreptocide, widely used for the treatment of Dermatophylosis and other skin diseases of various origin in all domestic animals and man. From June 2002 -2016, he was the Vet. Investigation Officer in charge of Southwest Regional Laboratory in Lagos. He was appointed Assistant Director in charge of Southwest zonal Laboratories in 2012 and Director Livestock Services in 2016. He has over fifty research publications in both local and international journals some of which he reviews their manuscripts for publication. He is also a co-author to two textbooks (Theory and Applications in Microbiology and Biotechnology and Vaccines in Developing Countries, Needs, Production Capacity and Immunization Strategies) in which he contributed a chapter each. Currently, he is a senior Lecturer in the Department of Veterinary Microbiology and Pathology, Faculty of Veterinary Medicine, University of Jos, Nigeria where he lectures various courses in different areas of Veterinary Microbiology at undergraduate level.

Administrative Experience: he has worked for almost twenty-nine years on the field as both the administrative head and Veterinary Investigation Officer in-charge of the National Veterinary Research Institute outstation laboratories. He was involved in some World Bank Projects including Trypanasomiasis research in the middle belt (Plateau,Nasarawa, Benue, Kogi and Kwara States), Seromonitoring of Rinderpest in the northeast zone, African Swine Fever and Avian Influenza in the southwest. 